\title{
Financial Development Influence on Economic Growth in Albania
}

\author{
Eugen Musta \\ PhD Cand. Lector at SHLUJ "Universiteti Marin Barleti”, \\ Department of Economics and Finance,
}

\begin{abstract}
During the 2000s the private banking sector in Albania started to consolidate and the level of lending in the economy started to grow. In the same period the overall economic indicators were showing positive growth too, but that all changed after the financial crisis of 2008. It took a while for its effects to hit the country but when they came the economy started to slowdown and the banks while facing a rise in Non-Performing Loans (NPL) started to cut out lending. The drop on lending is considered a problem by policy makers who see a pattern of causality in the finance - growth nexus based on theoretical works saying that finance development can influence growth. Even though the theory linking economic growth with financial development is not unanimously accepted on academic circles, empirical studies support the fact that a better developed financial system helps to support a sustainable growth. This seems enough to keep policy makers concerned with keeping lending high in the economy. The purpose of this study is to find if there is a pattern of such correlation between lending and growth in the Albanian economy. For the purpose data from the last 21 years have been analyzed through a time series regression where per capita GDP growth rate is the dependable variable and the domestic credit to private sector by banks is undependable variable. For the analyze is based on the aggregate demand model where credit is influencing investments, the influence which government spending may have on output is tested it the regression as an influential factor. The result showed that the explanatory variable coefficient is negative, suggesting that in this case the financial sector growth has a negative effect on growth. We assume this is so because the main channel through which the finance influences growth, which is by allocating capitals towards the most efficient opportunities, is not actually working and this can be seen by the high number of nonperforming loans on the banks' balance sheets.
\end{abstract}

Keywords: Lending, GDP growth, Albania, finance-growth nexus, financial development

JEL Classification: G010, G10, G20, G21, O40, E50, E51

\section{Introduction}

Albania was one of the last Eastern European countries to come out of communism in the early '90s. The process of transforming its economy from centralized to an open market one has been long and painful. By just looking at the GDP growth pattern one can notice big fluctuations specially in the first decade followed by a relatively more stable situation on the second decade and with a slow growth in the last few years. In the first decade after the fall of communism the economy had some good growth rate averaging to around $10 \%$ per year ${ }^{1}$, dropping to around $6 \%$ during the second decade and to only $2 \%$ on the last five years. Meanwhile the financial sector was very young and didn't had that much activity in the first decade (credit to private sector during that time averaged around $3 \%$ of GDP). During the 2000 s the private banking sector in Albania started to consolidate (Musta and Shehu, 2015) and the level of lending in the economy began to grow from around a ratio of $6 \%$ of the GDP to around $37 \%$ in 2010. In the same period the overall economic indicators were showing positive growth too, but that all changed after the financial crisis of 2008. It took a while for its effects to hit the country but when they came the economy started to slowdown and the banks while facing a rise in NPL (Non-Performing Loans) started

\footnotetext{
1 In our calculations here and forward we are excluding data from 1997 as outliers because of the specific social and political crisis which took place that year 
to cut out lending. This lead to a situation today when banks are holding excessive quantities of deposits and in the same time the lending is low. Because the correlation between credit and growth is very popular in theory, policy makers believe in a pattern of causality from finance to economic growth and are building policies to address the problem. Even though the theory linking economic growth with credit is not unanimously accepted on academic circles, empirical studies support the fact that a better developed financial system helps to support a sustainable growth.

While researching the literature, it resulted that there were no previous works conducted to test empirically this theory for Albania. This seemed odd considering the particular importance that has been given to the subject in the literature and the importance given by the government and specially by the Central Bank to the recent drop in lending and their concern with keeping credit high in the economy. Starting from here the purpose of this study is to find if there is a pattern of such correlation in the Albanian economy between lending and economic growth. For the purpose data from the last 21 years were gathered and analyzed through a time series regression. The per capita GDP growth rate is chosen as indicator for measuring economic growth and serves as a dependable variable and the domestic credit to the private sector supplied by the banking sector as un undependable variable. For the analyze is based on the aggregate demand model where we assume credit is mainly influencing investments. We also considered the influence which government spending's may have on total output.

\section{Research questions, hypothesis and objectives}

The purpose of this paper is to measure the effect of credit on economic growth in Albania. In pursue of this objective this study will try to answer to the question: How much influence has had the growth of credit on economic growth in the last 21 years and is the drop on lending accountable for the late drop in economic growth? In providing an answer to this questions, we are building upon two hypotheses:

H1 - Growth in lending has influenced positively the economic growth

$\mathrm{H} 2$ - The drop on lending in the recent years is influencing the economic growth rate drop

\section{Literature review}

In modern times finance is considered as one of the main components influencing, or even dictating the economic growth of a country. Based on this many developing countries give a great importance on developing the financial sector, while believing in his "healing" powers on poverty and growth. In the literature we find out that among the very first to promote this idea was Joseph Schumpeter. In the early 1911 he argued that the services provided by the financial intermediaries like: mobilizing savings, evaluating projects, managing risk, monitoring managers and facilitating transactions, are essential for technological innovation and economic development. Some of the first empirical studies about this topic were made during the early '70s. Works from economists like Goldsmith (1969), McKinnon (1973) and Shaw (1973) will became the base for promoting the role of financial development on economic growth. But not everyone agrees with that. The subject is more close to the case of the egg or the chicken. For some the direction of causation is that economic growth lead and financial development follows on it (Robinson, 1952) or according to Lucas (1988) the finance-growth nexus is just overestimated. But some kind of consensus is found on the ground that a robust and efficient financial system promotes growth by channeling resources to their most productive uses and fostering a more efficient allocation of resources. A stronger and better financial system can also lift growth by boosting the aggregate savings rate and investment rate, speeding up the accumulation of physical capital (Gemma et al., 2010). Dehejia and Lleras-Muney (2003) also confirmed that a well-functioning banking system boosts economic growth through improving capital allocation. But not all finance is good, and that was a lesson learned during the last crisis of 2008. Some studies show empirical results indicating that there is a finance threshold in the finance - growth nexus. For financial development below the threshold, finance will have a positive effect on economic growth which means that economic growth will be increased when financial development improves. But if the financial development exceeds the threshold, the impact of finance on growth will turn negative suggesting that further financial development will not translate into higher economic growth. We can find this same conclusion drown by the International Monetary Fund (IMF). They have suggested that the level of financial development is good only up to a point, after which it becomes a drag on growth. the relationship between finance and growth is a nonlinear one or, more specifically an inverted U-shape, where there is a turning point in the effect of financial development. Summarizing the findings form several studies this turning point may be found at the interval where private sector credit extended by banks is accounting for $80 \%$ to $100 \%$ of GDP (Cecchetti and Kharroubi (2012); Arcand et al. (2012); Shen and 
Lee (2006). On the other hand, Rioja and Valev (2004) are suggesting that there is also a low threshold level and that financial development exerts a strong positive effect on economic growth only when it has achieved a certain level or threshold of financial development; below this threshold, the effect is at best uncertain. To this same conclusion we find Dawson (2003) who in his study of on 13 transitional countries in Central and Eastern Europe found no significant effect of the financial development on the economic growth, ascertained that the economic growth in these countries was not limited by the underdeveloped financial sector. Mehl et al. (2005) went a little further because they not only didn't confirm that financial development causes positive economic growth for the nine countries of Southeast Europe used in their analysis, but the relation between financial intermediation and economic growth turned out to be a negative one. Their explanation on that was that because of the lower quality financial environment the development of the financial sector did not affect growth and economic efficiency. On the other hand, we find that Neimke (2003) proved that in transitional countries financial development had an impact on economic growth through increased investments and productivity, which are two of the major channels leading to growth. Also in countries with intermediate levels of financial development, the financial system has a large and positive effect on growth. However, for De Gregorio and Guidotti (1995) and Huang and Lin (2009) the positive effect of financial development on economic growth is much more significant in low-income and middle-income countries than in high-income countries. The reason for the non-linear relationship between finance and growth might be that financial development helps countries to catch up to the productivity frontier, but has limited or no growth effect for countries that are close to or at the frontier (Law and Singh, 2014). Deriving some conclusions from above we may say that the case may be more close to Al-Yousif's (2002) conclusion that the nature of the relationship between financial development and economic growth differs for different countries, because each of them has specific economic policies whose success depends on, among other things, the efficiency of the institutions which implement those economic policies. In addition, different studies cover different periods as well as the use of different research methods. While reviewing the empirical literature trying to classify different approaches used for testing the relation between financial development and economic growth we found from Demirgüç-Kunt and Levine (2008) that the literature contains four different types of studies: (i) pure cross-country growth regressions, (ii) panel techniques that make use of both the cross-country and time-series dimensions of the data, (iii) microeconomic studies that explore the various channels through which finance may affect economic growth, and (iv) individual country case studies. The first and second approach involves the application of broad cross-country growth regressions and panel data analysis seeking to explain growth through standard explanatory variables such as physical and human capital, to the study of finance and growth. These studies typically aggregate growth over long periods of time and examine the relationship between long-run growth and various measures of financial development. The third approach uses firm-level and industry-level data to assess the impact of financial development on firm and industry performance. A positive impact would lend support to the notion that financial development is beneficial for growth. The fourth drops the cross-country dimension and looks at the finance growth in a single individual country. Although most of the empirical studies on the subject suggest that financial development has an important impact on economic growth, the effect is not always positive. Deheja and Lleras-Muney (2005) argue that indiscriminate expansions of credit, such as the one that resulted from deposit insurance laws, can have a negative impact on growth. For this reason, it is important not only to focus on financial development but also on the choice of institutional mechanisms influencing and regulating it.

\section{Methodology}

This paper approach in trying to test the relation between finance development and economic growth in Albania will be based on an individual country case model. For the purpose will be used time series data stretching from the earliest data available which is from the year 1994 up to 2015 . The gathered data will be analyzed through an ordinary least squares model regression based on linear growth equation. While reviewing the data was noticed that because of the unusual events unfolded during 1997 in Albania which consisted of a high level of political and civil instability (being quasi at the verge of a civil war), the economic data of that year had an outlier behavior. Because of this the records from that year were excluded from analysis.

\section{Empirical Model}

To investigate whether the exogenous component of financial development positively influences economic growth, a growth regression model is set up with the annual growth rate of per capita GDP as the dependent variable. The independent variables include a variable representing financial development and a control indicator for influences from the real sector to growth. The empirical model is based on King and Levine (1993a, 1993b), Levine and Zervos (1998), Cecchetti and 
Kharroubi (2012), Zhang et al. (2012) and others who propose a linear growth equation to examine the linkages between finance and growth.

$$
\text { Growth }=\beta_{0}+\beta_{1} D C B S+\beta_{2} G o v+\varepsilon
$$

For this study, we collected proxy measures for financial development, real sector and economic growth from the World Bank's - World Development Indicators 2009 (WDI) database for the period from 1994 to 2015. In our analysis, we used GDP per capita growth rates as a proxy for economic growth (Growth). We also used domestic credit provided by the banking sector as a percentage of GDP (DCBS) as proxy to measure financial development and the size of the real sector. Higher DCBS indicates a higher degree of dependence upon the banking sector for financing. In other words, higher DCBS implies higher financial development because banks are more likely to provide the five financial functions discussed in Levine (1997) and Levine, Loayza and Beck (2000). Financial systems that allocate more credit to the private sector are more likely to be engaged in researching borrower firms, exerting corporate control, providing risk management control, facilitating transactions, and mobilizing savings (Levine, 2005), which requires a higher degree of financial development. To control for influences from the real sector to growth we used the ratio of general government final consumption expenditure to GDP (GOV). It effectively measures the weight of fiscal policy as many developing countries tend to use expansionary or contractionary fiscal policies for steady economic growth by adjusting government spending.

Table 1: Variable Description

\begin{tabular}{|c|c|c|c|c|c|c|}
\hline Variable & Indicator & Proxy & Abbrev. & Source & Authors & $\begin{array}{l}\text { Exp } \\
\text { corr. }\end{array}$ \\
\hline 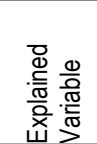 & $\begin{array}{l}\text { Economic } \\
\text { Growth }\end{array}$ & $\begin{array}{l}\text { GDP per capita } \\
\text { growth rate }\end{array}$ & Growth & World Bank & $\begin{array}{l}\text { Claessens and Laeven (2005), Deidda } \\
\text { and Fattouh (2002), Vives (2001), Bikker } \\
\text { and Haaf (2002), (Sathye, 2002), } \\
\text { (Athanasoglou et al., 2005), etc. }\end{array}$ & \\
\hline \multirow[b]{2}{*}{ 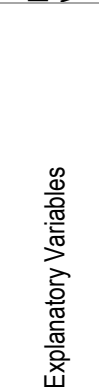 } & $\begin{array}{l}\text { Financial } \\
\text { developme } \\
\text { nt }\end{array}$ & $\begin{array}{l}\text { Credit to } \\
\text { private sector } \\
\text { provided by } \\
\text { banks as } \\
\text { percentage of } \\
\text { GDP }\end{array}$ & DCBS & $\begin{array}{l}\text { World } \\
\text { Bank's World } \\
\text { Development } \\
\text { Indicators }\end{array}$ & $\begin{array}{l}\text { Levine, Loayza and Beck, (2000), King } \\
\text { and Levie (1993), Levine and Zervos, } \\
\text { 1998; Calderón and Lui, } 2003\end{array}$ & + \\
\hline & $\begin{array}{l}\text { Control } \\
\text { variables }\end{array}$ & $\begin{array}{l}\text { General } \\
\text { government } \\
\text { final } \\
\text { consumption } \\
\text { expenditure (\% } \\
\text { of GDP) }\end{array}$ & GOV & $\begin{array}{l}\text { World } \\
\text { Bank's World } \\
\text { Development } \\
\text { Indicators }\end{array}$ & $\begin{array}{l}\text { Estrada et al. (2010), Imam et al. (2015), } \\
\text { etc. }\end{array}$ & + \\
\hline
\end{tabular}

Source: Author

\section{Data analyses}

\section{Regression 1.}

Model 16: OLS, using observations 1994-2015 ( $T=21)$

Dependent variable: Growth

$\begin{array}{llclll} & \text { Coefficient } & \text { Std. Error } & \text { t-ratio } & \text { p-value } & \\ \text { const } & 7.13118 & 5.32493 & 1.3392 & 0.1972 & \\ \text { DCBS } & -0.16914 & 0.0344285 & -4.9128 & 0.0001 & * * \\ \text { GOV } & 0.200687 & 0.479955 & 0.4181 & 0.6808 & \end{array}$




$\begin{array}{llll}\text { Mean dependent var } & 5.951582 & \text { S.D. dependent var } & 3.458665 \\ \text { Sum squared resid } & 101.1004 & \text { S.E. of regression } & 2.369955 \\ \text { R-squared } & 0.577423 & \text { Adjusted R-squared } & 0.530470 \\ \text { F }(2,18) & 12.29789 & \text { P-value }(F) & 0.000430\end{array}$

After running the regression, the first thing to notice is the unexpected negative sign of the explanatory variable. Which is contradicting the positive effect which finance has on economic growth as theory suggests. Nonetheless, the result is statistically significant to the level of $1 \%$ and also the $R$ squared is reading 0.577 while the adjusted $R$-squared is at 0.53 which means that the variable explains the behavior of the dependable variable at $53 \%$. Looking at the second variable which is the government expenditure as expected in accordance to Keynesians macroeconomic model, government expenditure has a positive correlation with growth in this case at 0.2 . But the result is statistically non-significant. On the second regression the control variable is taken out and as expected it doesn't affect the results. This time as can be seen from the table the financial indicator has still a negative influence on the dependable variable and the reading is statistically significant on the level of $1 \%$ with an adjusted R-squared of 0.55 . In the second regression the constant also becomes statistically significant at the level of $1 \%$.

\section{Regression 2.}

Model 17: OLS, using observations 1994-2015 ( $T=21)$

Dependent variable: Growth

$\begin{array}{llllll} & \text { Coefficient } & \text { Std. Error } & t \text {-ratio } & p \text {-value } & \\ \text { const } & 9.3287 & 0.838199 & 11.1295 & <0.0001 & * * * \\ \text { DCBS } & -0.1699 & 0.0336256 & -5.0527 & <0.0001 & * * *\end{array}$

$\begin{array}{llll}\text { Mean dependent var } & 5.951582 & \text { S.D. dependent var } & 3.458665 \\ \text { Sum squared resid } & 102.0824 & \text { S.E. of regression } & 2.317921 \\ \text { R-squared } & 0.573318 & \text { Adjusted R-squared } & 0.550861 \\ \text { F }(1,19) & 25.52968 & \text { P-value(F) } & 0.000071\end{array}$

\section{Conclusions}

The purpose of this paper was to test the relation between financial development and economic growth in Albania. Contrary to the expectation and the assumption of $\mathrm{H} 1$ the result turned out to be negative. Meaning that the current financial expansion is actually having a negative effect on the economic growth of the country. Even though this result was unexpected it is not unknown in the literature. Rioja and Valev (2004) suggested a low threshold level, below this threshold they stated that the effect is at best uncertain. More close to this paper conclusion is Mehl et al. (2005) who not only didn't confirm that financial development causes positive economic growth for the nine countries of Southeast Europe used in their analysis, but the relation between financial intermediation and economic growth for them too, turned out to be a negative one. Their explanation was that because of the lower quality financial environment the development of the financial sector did not affect growth and economic efficiency.

According to Backe et al. (2006) in transitional countries the financial system is mainly based on banks whose assets accounted for approximately $85 \%$ of total financial sector assets. This means that capital markets are underdeveloped making the banking sector the most important channel of financial intermediation. This is the case for Albania too, and in it may lay the reason for the negative effect finance has on growth. This conclusion may be derived considering the high amount of non-performing loans the banks faced since 2011. Literature suggests that one of the main channels through which finance can influence growth is through allocating funds towards the most efficient opportunities and apparently is 
exactly this function which failed. And so by not allocating efficiently the otherwise scarce capitals of an underdeveloped economy the banking sector can have a negative effect on growth.

Another reason for the negative effect on growth in the Albanian case may be that the most of the financing used in the country during this period went on consumer loans. As Hung (2009) point out while financial development facilitates investment loans that tend to promote growth, consumption loans which are non-productive tend to impede growth. To the same conclusion we find Beck et al. (2012) who also argue that enterprise and household credit plays a key role in shaping the relationship between finance and growth. They find that the growth effect of financial development comes through enterprise rather than household credit to drive the positive impact.

In the end we hope the conclusions of this study will help pave the road to more research on the finance - growth nexus in Albania and that these findings will serve to policy makers for focusing more on policies which improve the quality and functions of financial intermediaries and not only on the size of the sector, because as this study concluded there is no need for higher crediting in the economy if the effect on growth is negative ${ }^{1}$.

\section{Bibliography}

[1] Al-Yousif, Y. K. (2002), "Financial Development and Economic Growth: Another Look at the Evidence from Developing Countries." Review Financial Economics, Vol. 11, No. 2, pp. 131-150.

[2] Arcand, J. L., Berkes, E., Panizza, U., 2012. Too much finance? IMF Working Paper 12/161.

[3] Backé, P., Égert, B., Zumer, T. (2006), "Credit Growth in Central and Eastern Europe: New (Over) Shooting Stars?" ECB Working Paper Series No. 687.

[4] Beck, T., Degryse, H., Kneer, C., 2012. Is more finance better? Disentangling intermediation and size effects of financial systems, Center for Economic Research, Discussion Paper No. 2012-060, Tilburg University.

[5] Calderón, C., Liu, L. (2003), "The Direction of Causality between Financial Development and Economic Growth." Working Paper No. 184. Central Bank of Chile.

[6] Cecchetti, G., Kharroubi, E., 2012. Reassessing the impact of finance on growth. BIS Working Papers No. 381, Bank for International Settlements.

[7] Cecchetti, G., Kharroubi, E., 2013. Why does financial sector growth crowd out real economic growth? Finance and the Wealth of Nations Workshop, Federal Reserve Bank of San Francisco \& The Institute of New Economic Thinking, Sept 27, 2013.

[8] Cetorelli, N., Gambera, M. (2001). "Banking Market Structure, Financial Dependence and Growth: International Evidence from Industry Data," Journal of Finance, 56(2), 617-648.

[9] Dawson, P.J. (2003), "Financial Development and Growth in Economies in Transition." Applied Economics Letters, Vol. 10, No. 13, pp. 833-836.

[10] De Gregorio, J., Guidotti, P., 1995. Financial development and economic growth. World Development 23(3), 433448.

[11] Demirgüç-Kunt, A., and R. Levine. 2008. Finance, Financial Sector Policies, and Long-Run Growth. Policy Research Working Paper WPS4469, The World Bank, Washington, DC.

[12] Dehejia, R., Lleras-Muney, A. (2003). "Why Does Financial Development Matter? The United States from 1900 to 1940." National Bureau of Economic Research, Working Paper No.9551.

[13] Estrada G., Park D., and Ramayandi A. (2010). "Financial Development and Economic Growth in Developing Asia". ADB Economics Working Paper Series No. 233

[14] Gemma E., Donghyun P., and Arief R., (2010). "Financial Development and Economic Growth in Developing Asia". ADB Economics Working Paper Series No. 233

[15] Goldsmith, R. (1969). Financial Structure and Development. New Haven, CN: Yale University Press.

\footnotetext{
1 This conclusion is automatically ruling out $\mathrm{H} 2$
} 
[16] Guiso, L., Sapienza, P., Zingales, L. (2004). "Does Local Financial Development Matter?" Quarterly Journal of Economics, 119(3), 929-969.

[17] Huang, H. C., Lin, S. C., 2009. Non-linear finance-growth nexus. Economics of Transition 17, 439-466.

[18] Hung, F. S., 2009. Explaining the nonlinear effects of financial development on economic growth. Journal of Economics 97(1), 41-65.

[19] Imam, P., Kpodar, K., (2015). Is Islamic Banking Good for Growth? International Monetary Found - Working paper $15 / 81$

[20] King, G. R., Levine, R., 1993a. Finance and growth: Schumpeter might be right. Quarterly Journal of Economics 108(3), 717-737.

[21] King, G. R., Levine, R., 1993b. Finance, entrepreneurship and growth. Journal of Monetary Economics 32(3), 1-30.

[22] Kumar, K. B., Rajan, R.G., Zingales, L. (1999). "What Determines Firm Size?" National Bureau of Economic Research, Working Paper No.7208.

[23] Law, S,. Singh, N., (2014). "Does to much finance harm economic growth? "Journal of banking and Finance. Volume 41, pages 36-44

[24] Levine, R., Zervos, S., 1998. Stock markets, banks and economic growth. American Economic Review 88(3), 537558.

[25] Levine, R. (2005). "Finance and Growth: Theory and Evidence." Handbook of Economic Growth, Amsterdam, Netherlands, Elsevier, Chapter 12, 1(1), 865-934.

[26] Levine, R., Loayza, N., Beck, T. (2000). "Financial Intermediation and Growth: Causality and Causes." Journal of Monetary Economics, 46(1), 31-77.

[27] Lucas, R. E. (1988), "On the Mechanics of Economic Development," Journal of Monetary Economics, 22, 3-42.

[28] McKinnon, R. (1973). Money and Capital in Economic Development. Washington, DC: Brookings Institution.

[29] Mehl, A., Vespro, C., Winkler, A. (2005), "The Finance-Growth Nexus and Financial Sector Environment: New Evidence from Southeast Europe." Conference on European Economic Integration, Austrian National Bank, Vienna.

[30] Neimke, M. (2003), "Financial Development and Economic Growth in Transition Countries." IEE Working Papers 173.

[31] Jayaratne, J., Strahan, P.E. (1996). "The Finance-Growth Nexus: Evidence from Bank Branch Deregulation." Quarterly Journal of Economics, 111(3), 639-670.

[32] Obradovic, S., Grbic, M., (2015). Causality Relationship Between Financial Intermediation by Banks and Economic Growth: Evidence from Serbia. Prague Economic Papers, Vol. 24, Nr. 1

[33] Rioja, F., Valev, N., 2004b.Finance and the sources of growth at various stages of economic development. Economic Inquiry 42(1), 127-140.

[34] Rajan, R. G., Zingales, L. (1998). "Financial Dependence and Growth." American Economic Review, 88(3), 559586.

[35] Siong, H. L., Nirvikar, S. 2014. Does Too Much Finance Harm Economic Growth? Journal of Banking and Finance 41 (2014), 36-44

[36] Schumpeter, J. (1911). The theory of Economic Development. Cambridge, Ma: Harvard University Press.

[37] Shen, C. H., Lee, C. C., (2006). Same financial development yet different economic growth- why? Journal of Money, Credit and Banking 38 (7), 1907 -1944.

[38] Jin, ZH., Lanfag, W., Susheng, W. 2012. Financial development and economic growth: Recent evidence from China. Journal of Comparative Economics. Volume 40, Issue 3, August 2012, Pages 393-412

[39] Wurgler, J. (2000). "Financial Markets and the Allocation of Capital." Journal of Financial Economics, 58(1-2), 187214. 